\title{
LAPAROSCOPIC ANATOMY OF CAPRINE ABDOMEN AND LAPAROSCOPIC LIVER BIOPSY
}

Kassem M.M., Abdel-Wahed R.E., El-Gendy S. ${ }^{*}$ and El-Kammar M.H. (Dept. of Surgery and Anatomy*, Fac. Vet. Med., Alex. University)

\section{ABSTRACT}

This study was carried out on (10) apparently healthy adult non pregnant female baladi goats weighting 205-30 kg and aging 1.5-3 years old to provide normal laparoscopic anatomy of the abdomen and to assess feasibility of laparoscopy for liver biopsy. Following preparation of animals, equipments and instruments, the primary port and laparoscope was placed on the umbilicus and $360^{\circ}$ scan was performed for orientation and exploration of the abdominal cavity. Secondary ports were placed under direct laparoscopic observation to allow insertion of accessory instruments for tissue grasping, coagulation and severing. The obtained results cleared that ventral laparoscopic approach and tilting and rotating the animal during laparoscopic procedures provided better exposure of internal abdomen. Laparoscopy provided a comprehensive description of cranial and caudal abdominal regions offering good visualization of the liver, gallbladder, reticulum, abomasum, intestine, spleen, reproductive organs and urinary bladder. Laparoscopic liver biopsy required two secondary ports; one $5 \mathrm{~mm}$ assisting port inserted in right subcostal area and one operating port inserted subxiphoid. The procedure was safe, practical and easily performed offering the advantage of direct visualization of liver and selection of the exact biopsy site. Wedge biopsy technique proved advantageous than the Tru-cut needle biopsy technique. 


\section{INTRODUCTION}

Laparoscopy is a minimally invasive technique for viewing the internal organs of the abdominal cavity. The equipment used during laparoscopy provided the surgeon with a live picture of the inside of the abdominal cavity (Freeman, 1999; Nord, 1987 and Maxwell and Kraemer, 1980). A smaller diameter (5 $\mathrm{mm}$ and $30^{\circ}$ ) laparoscope had been used successfully in sheep and goats (Dukelow et al., 1971; Jarosz et al., 1971). While, Chamness (2002) used $10 \mathrm{~mm}$ outer diameter telescope in both equine and human laparoscopy. Laparoscopy had many applications as diagnostic, therapeutic and prognostic purposrs. It could be used to biopsy specific sites of the abdominal viscera (Bleyaert et al., 1997 and Boure et al., 2002). Laparoscopy also allowed visualization of some structures not seen in standard celiotomy approach. Accurate knowledge of normal visceral anatomy is essential for performing diagnostic and therapeutic laparoscopic procedures and allows more accurate diagnosis of pathologic conditions and precise decisions for surgical intervention (Galuppo et al., 1995 and Galuppo, (2002). Laparoscopy could be a useful teaching aid for students, facilitating better understand of anatomy and in the development of rectal palpation skills (Smith et al., 2005). The present study aimed to provide description of normal laparoscopic anatomy of the abdomen of female goats and to assess the feasibility of laparoscopy for liver biopsy, using two techniques, considering goats as a good model for ruminant. 


\section{MATERIALS AND METHODS}

This study was carried out on (10) apparently healthy adult non pregnant female Baladi goats weighting 25-30 kg and aging 1.5-3 years old at Alexandria Endoscopy Association (ALEXEA). They were fasted for 12-24 hrs prior to laparoscopy. Laparoscopic equipments and instruments of Storz, Tuttlingen/Germany were used (Fig., 1). $10 \mathrm{~mm}$ diameter, $35 \mathrm{~cm}$ length, straight forward Hopkins with $0^{\circ}$ viewing angle of vision and a forward-oblique with $30^{\circ}$ viewing angle telescopes were used. Laparoscopy was performed under the effect of inhalation general anesthesia according to the technique described by Muir and Hubbell (1989). Goats were placed in dorsal recumbency with their legs tied to the surgical table (Fig., 2 A). Animal was subjected to aseptic surgical preparation and draping (Fig., 2 B). Ventral midline was taken as a basic laparoscopic surgical approach and pneumoperitoneum was conducted according to the technique described by Ivankovich (1975) and Liem et al. (1994). The laparoscope was passed through the cannula of the primary port into the peritoneal cavity (Fig., 2 C\&D). Systemic examination of the entire abdominal viscera was done by video camera connected to the eye piece of the laparoscope and the images were transferred through the control unit to the TV monitor and recording on a video tape. A $360^{\circ}$ scan was performed for orientation and to determine if trauma caused by the cannula insertion had occurred. The animal was tilted from head up (reverse Trendelenburg position) to head down (Trendelenburg position) or to neutral to shift abdominal viscera and expose the surgical site. Secondary ports were inserted to allow passage 
of accessory instruments used for manipulation of abdominal viscera and to perform laparoscopic liver biopsy. Secondary ports were inserted in locations that provide optimal access to the organ of interest. They were inserted while the tip of the laparoscope was retracted backward during insertion to monitor entry of the trocar into the abdominal cavity (Fig., 2 E\&F). Laparoscopic examination of the abdomen in dorsally recumbent goats was accomplished by two body positions; head up and head down position according to the technique described by Babkine and Desrochers (2005). Liver biopsy was carried out while the animal positioned in dorsal recumbency and slightly head up. Three ports were used; one optical $(10 \mathrm{~mm})$ and two $5 \mathrm{~mm}$ secondary ports including one operating port and one assisting port (Fig., 2 B). Tru-Cut needle biopsy technique was performed after the liver was inspected where the needle was inserted under laparoscopic vision through the abdominal wall, directly above and perpendicular to the selected area. The barrel of the Tru-Cut was advanced to obtain the specimen. The needle was removed and cautery was used to ensure hemostasis. Laparoscopic wedge biopsy of the liver was carried out according to Falcone et al. (1993) where a fenestrated grasping forceps was passed through the left secondary port and directed cranially to clamp the edge of the liver at an approximately $90^{\circ}$. A $5 \mathrm{~mm}$ bipolar electrosurgical forceps was inserted through the right secondary port and created wedge shape section of liver for biopsy. Laparoscopic scissors was inserted to excise the specimen that was removed from the abdomen through the instrumental portal, after removal of the trocar sheath. The biopsy site was observed for any bleeding. 


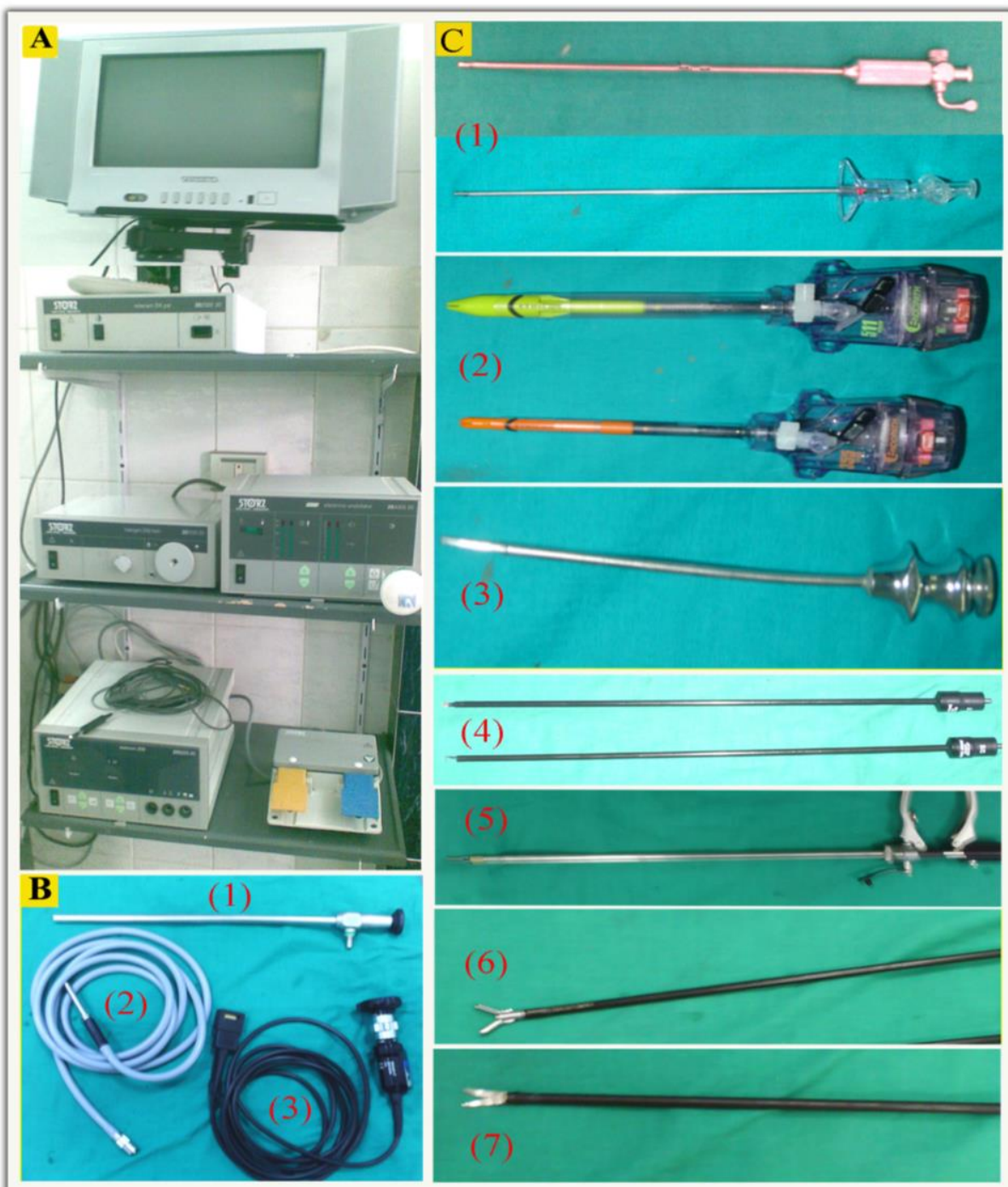

Fig. (1): Showing laparoscopic equipments and instruments; (A) laparoscopic tower from top to bottom, T.V. monitor, camera control unit, light source (left), insufflator (right) and generator with its dual pedal foot switch and power cord; (B) diagnostic laparoscope (1), light cable (2) and video camera (3) and (C) laparoscopic instruments; reusable and disposable Veress needle (1), disposable $10 \& 5 \mathrm{~mm}$ trocar and cannula (2), Tru-cut biopsy needle (3), spatula \& mono-polar electrode (4), reusable bipolar forceps (5), grasping forceps (6) and curved scissors (7). 


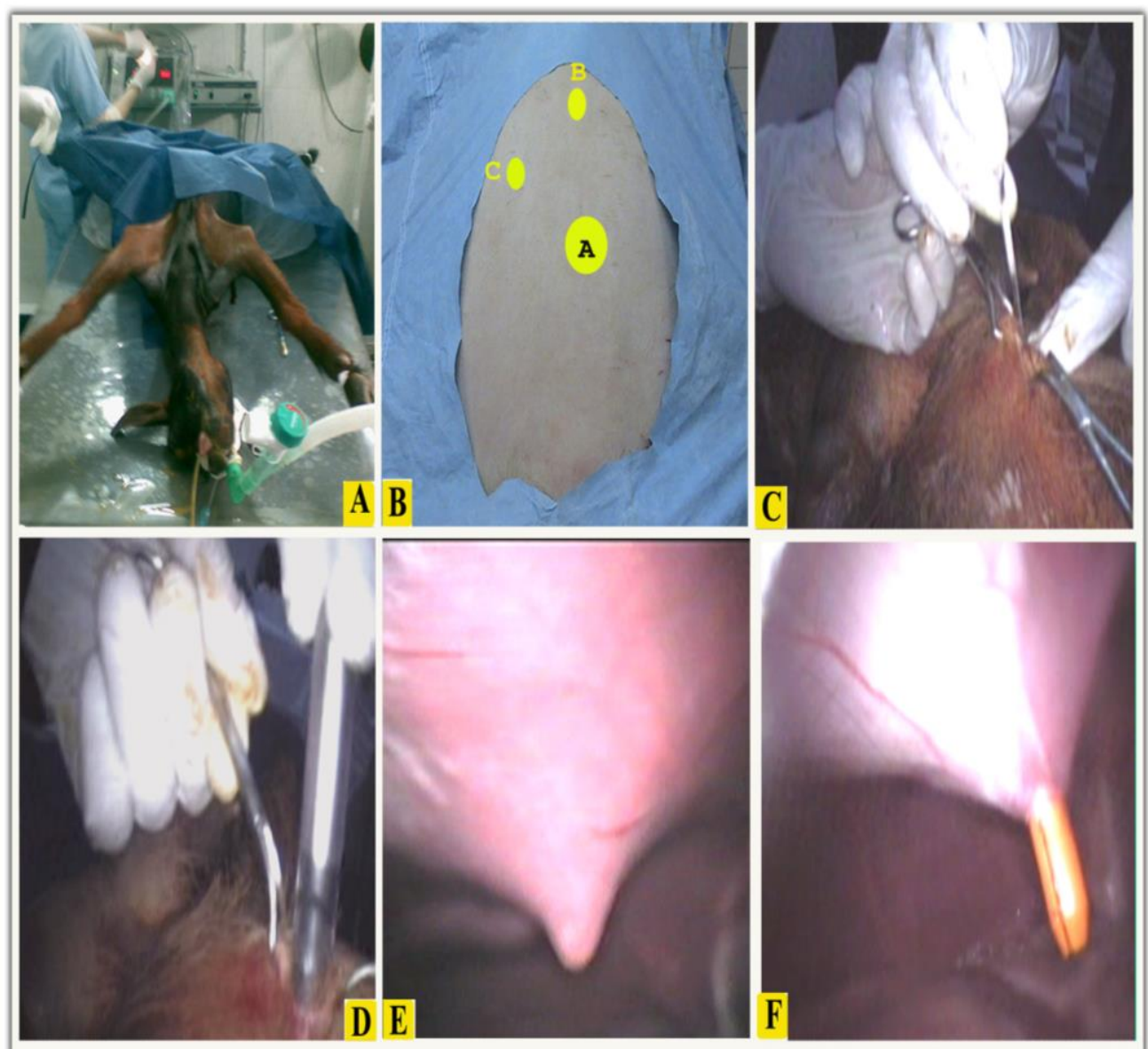

Fig. (2): Showing dorsal recumbent anesthetized goat (A), prepared ventral abdomen with illustrations for sites of primary $(A)$ and secondary ports $(B \& C)$, intraumbilical stab incision (C), primary trocar insertion (D) and peritoneal view of insertion of secondary ports (E\&F). 


\section{RESULTS}

\section{1- Anatomical findings:}

Transumbilical laparoscope insertion allowed optimum observation of the viscera in all position of the abdomen. Tilting and rotating the animal during laparoscopic procedures provided better exposure of area of interest. Reverse Trendelenburg position (head up) encouraged abdominal organs to slide caudally exposing cranial operative site (Figs., 3\&4). Trendelenburg position (head down) encouraged abdominal organs to slide cranially exposing caudal operative site (Fig., 5).

\section{1- Cranial abdominal region:}

Central tendinous portion of diaphragm, diaphragmatic surface of the liver, reticulum, abomasum and greater omentum were easily identified by orienting the laparoscope cranially and in a sagittal plane. The right and left phrenic veins located on the left and right halves of the tendinous portion of the diaphragm were observed extending centrally toward the vena cava (Fig., 3 A). The diaphragmatic surface of the liver was easily viewed draping over the reticulum and intestine by orienting the laparoscope to the left in the cranial portion of the abdomen (Fig., 3 B). Observation of the visceral surface and hilus of the liver required elevation of the liver by liver retractor. The visceral surface appeared related to the reticulum, omasum, lesser omentum, cranial part of the duodenum and the right kidney. The caudate process of the liver appeared capping the cranial pole of the right kidney after tilting the animal to the left and retracting the greater omentum by grasping forceps (Fig., 3 C \& D).

The reticulum was situated in the intra-thoracic part of the abdominal cavity occupying the left hypochondriac region recognized by its regular contractions. It was contacted with diaphragm cranially, the 
left ventral abdominal wall laterally, the left lobe of the liver medially and abomasum and greater omentum caudally. The abomasum was recognized by its serosa and its attachment to the greater omentum that created contrast with the smooth portion of the serosa (Fig., 3 B). The reticuloabomasal ligament was identified by retracting reticulum dorsally toward diaphragm using two grasping forceps (Fig., $3 \mathrm{E}$ ).

Ventral extremity of the spleen appeared after separating the left abdominal wall and ventral ruminal sac using accessory instrument (Fig., 3 F).

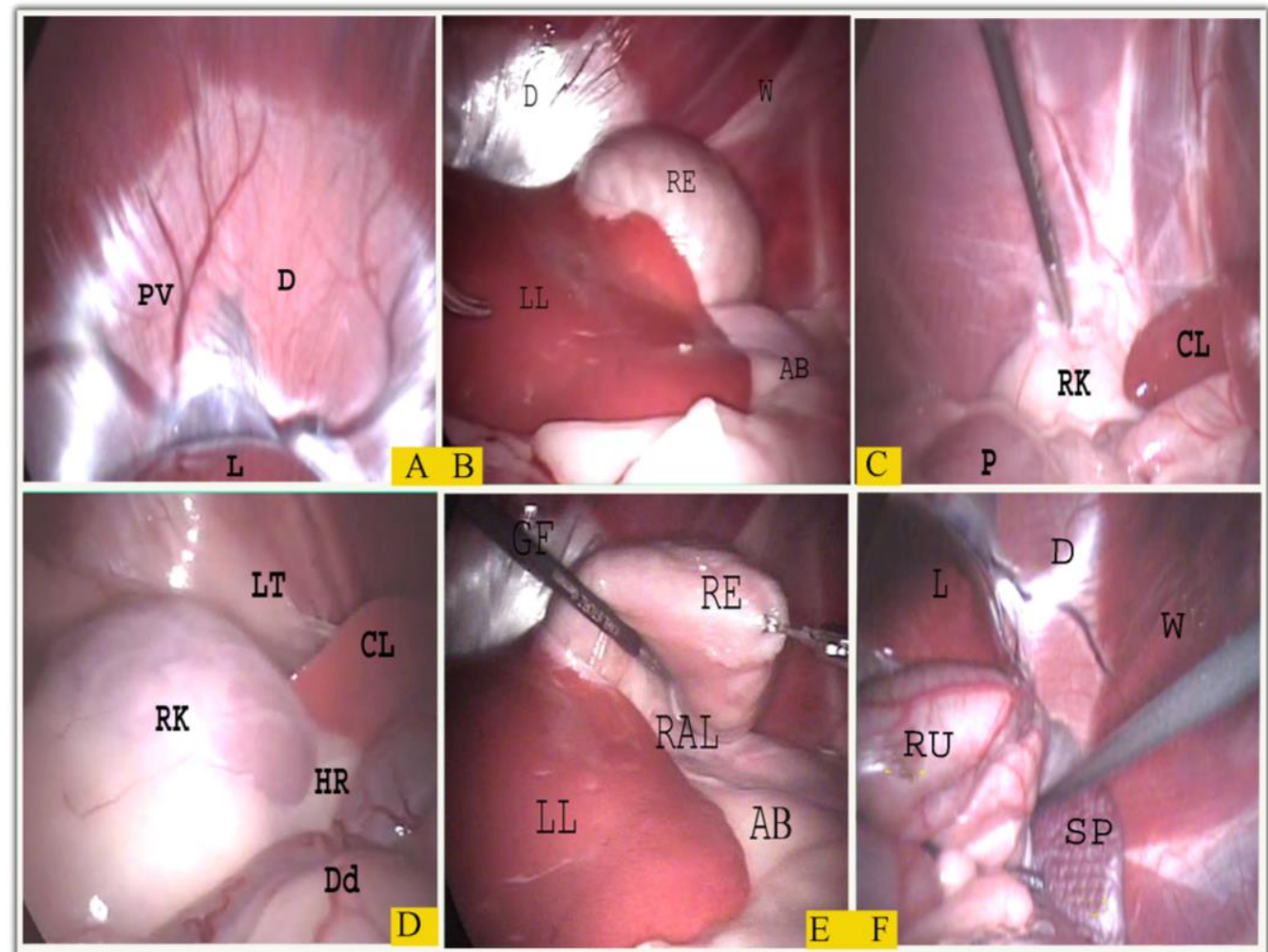

Fig.(3): Showing laparoscopic view of cranial region of abdomen of female goat in reverse Trendelenburg position. Where: D, central tendinous portion of diaphragm; PV, phrenic veins; $\mathrm{L}$, diaphragmatic surface of liver; $\mathrm{LL}$, left lobe of the liver; RE, reticulum; $\mathrm{AB}$, abomasum; RU, ventral ruminal sac; RAL, reticuluabomasal ligament; SP, spleen and $\mathrm{W}$, abdominal wall.

$\overline{\text { Kafrelsheikh Vet. Med. J. Vol. } 6 \text { No. } 1 \text { (2008) }}$ 
The gallbladder proved projecting lower the ventral hepatic border and embedded between the right and quadrate lobes (Fig., 4). Complete exposure of the gallbladder necessitated elevation of the right lobe using accessory instruments. The extrahepatic biliary system seemed as a continuation of the cystic duct, which continued as the common bile duct after its conjunction with the hepatic duct (Fig., 4 C-E).

Caudal view in the head up position allowed nothing except greater omentum and prepupic tendon (Fig., 4 F).

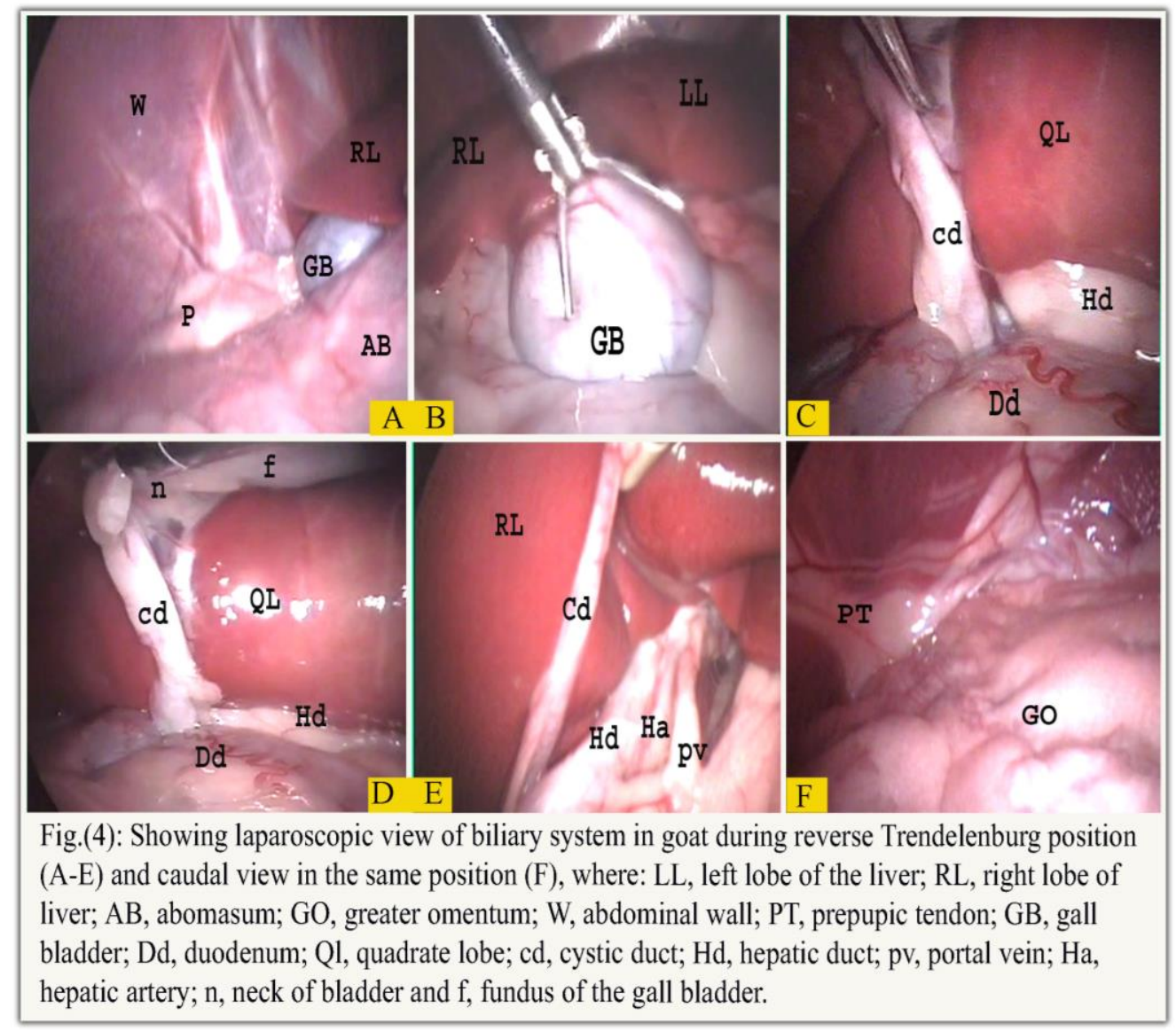

$\overline{\text { Kafrelsheikh Vet. Med. J. Vol. } 6 \text { No. } 1 \text { (2008) }}$ 


\section{2- Caudal abdominal region:}

By orienting the laparoscope caudally and in a sagittal plane, urinary bladder, coiled uterine horn, pudendoepigastric vessels, rectus abdominus muscle, prepupic tendon, internal abdominal oblique, segments of the jejunum and descending colon were identified easily without any manipulation (Fig., 5 A). Urinary bladder appeared as a hollow muscular organ varied in size according to the state of fullness with urine having pinkish-grey coloration and tortuous serosal vessels on its surface. The lateral ligaments were observed extending from the apex of the bladder toward the lateral aspect of the pelvic cavity after elevation of the bladder by accessory instrument (Fig., 5 B).

Apex of the cecum appeared as cylindrical barrel shaped organ after its pulling out of the supraomental recess and folded them cranially. The descending colon was identified by its segmentation into the pellets and its fecal contents (Fig., 5 C).

The two ovaries, their proper ligaments and mesovarium, uterine tubes, broad ligaments and uterine horns were observed after manipulation of the overlying segments of the gastrointestinal tract and elevation of the uterus by accessory instruments. Body of the uterus and rectogenital pouch was viewed easily after elevation of the uterus against the ventral abdominal wall by two accessory instruments (Fig., 5 D-F). Ovaries were best viewed after the mesovarian ligaments were picked-up by accessory instrument. The position of the animal turned slightly to the right or the left during manipulation to obtain the better view of ovaries and their structures as well as blood supply. The ovaries appeared as spherical but slightly flattened organ and located craniolateral to the pelvic inlet at the tip of the uterine tube. Laparoscopy provided better understand of position of supporting structures of the uterus and ovaries. The ovaries were suspended in the abdominal cavity by proper and mesovarian ligaments. The mesovarium appeared as the cranial portion of the broad ligament suspending ovaries with the lateral abdominal wall 
and through which blood vessels, lymphatics and nerves passed to the ovary. The cyclic morphological alterations were detected on the ovaries, including ovarian follicle and corpus luteum (Fig., $5 \mathrm{G}$ ). The uterine tube appeared rounded and tortuous with light pinkish color. The tubes were best exposed when the mesovarium was picked-up away from the examined field by accessory instrument (Fig., $5 \mathrm{H}$ ). Ureters were observed laparoscopically before entering the broad ligament after its elevation by accessory instrument (Fig., 5 I). Dorsally located abdominal structures including left kidney, root of mesentery, base of the cecum and dorsal part of the spleen were not visible in the dorsally recumbent goat.

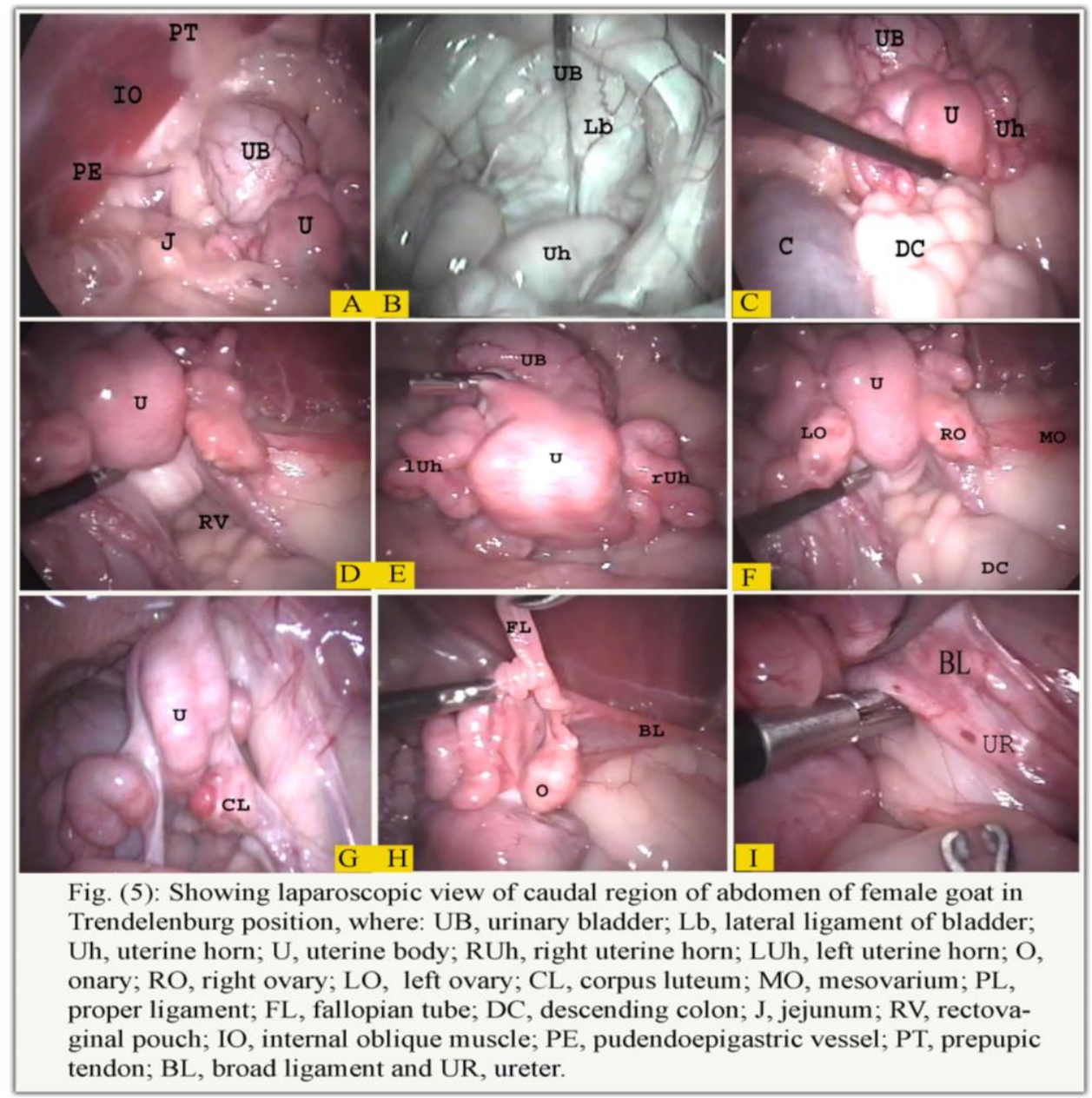

$\overline{\text { Kafrelsheikh Vet. Med. J. Vol. } 6 \text { No. } 1 \text { (2008) }}$ 


\section{2- Laparoscopic liver biopsy:}

Laparoscopy enabled larger specimens and exposing multiple area of the liver at one time. Samples were easily taken from all liver lobes. Laparoscopic guided needle biopsy provided fast technique. Angulated needle biopsy approach resulted in inadvertent perforation of the underlying structures rather perpendicular needle approach.Laparoscopic wedge biopsy of liver easily accomplished along the edge of the liver resulting in larger liver biopsy specimen but needed two additional $5 \mathrm{~mm}$ trocars. Both biopsy techniques resulted in minimal hemorrhage. Hemorrhage following needle biopsy technique was significant (by visual examination) than that following wedge biopsy technique (Fig., 6). Post-biopsy bleeding was the only possible complication occurring with Tru-cut biopsy needle. Direct compression and electrocautery applied to biopsy site was sufficient to ensure hemostasis.

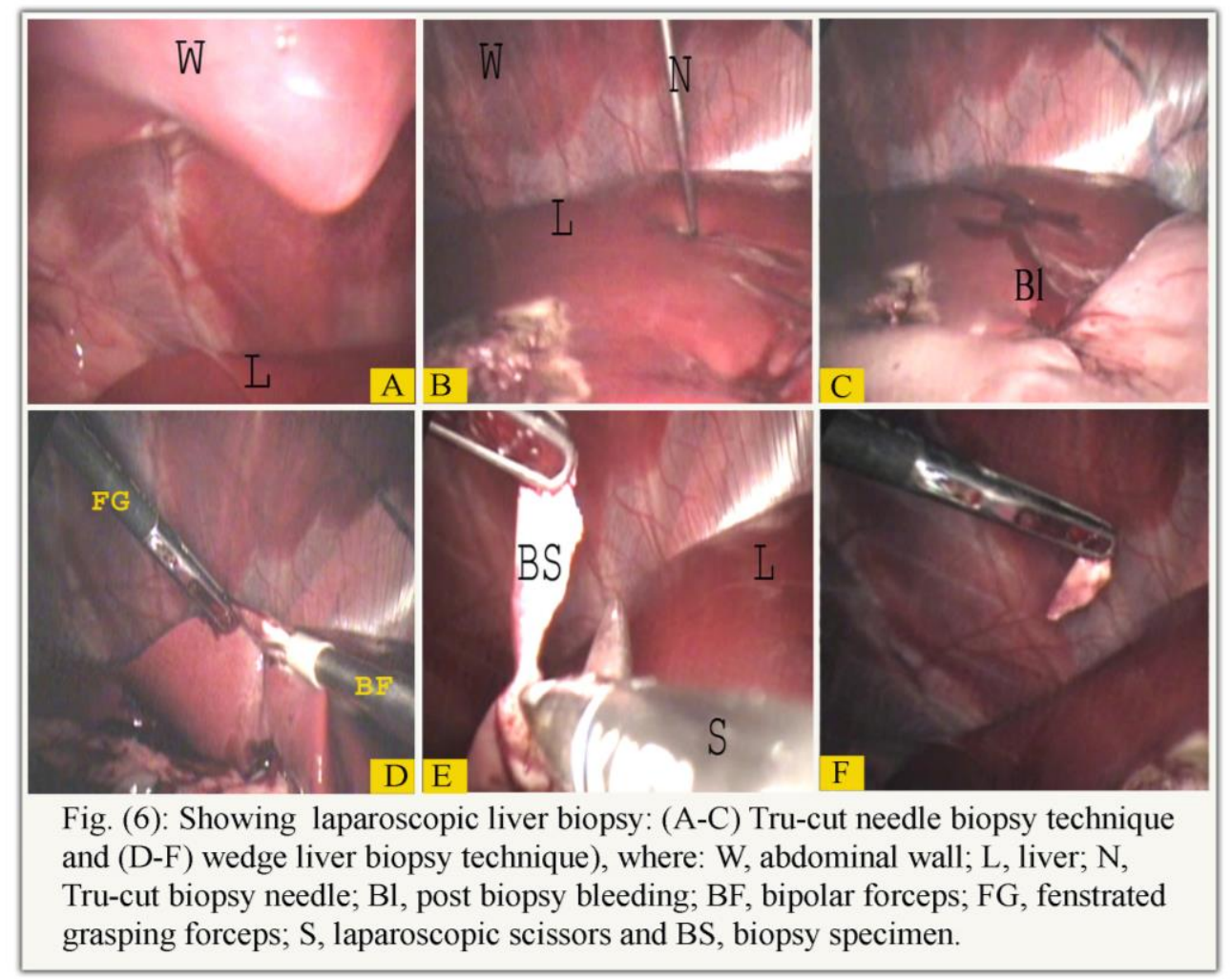

$\overline{\text { Kafrelsheikh Vet. Med. J. Vol. } 6 \text { No. } 1 \text { (2008) }}$ 


\section{DISCUSSION}

In the present study, usage of $10 \mathrm{~mm}$ outer diameter laparoscope was preferred as it provided good panoramic and close-up view. Usage of $0^{\circ}$ laparoscope proved advantageous than $30^{\circ}$ laparoscope. Prescott (1980), Freeman (1999) and Chamness (2002) found this type of laparoscope allowing orientation and manipulation of instruments easier. It also maximized light transmission compared with laparoscopes with an offset viewing angle ( $30^{\circ}$ laparoscope). Usage of Halogen 250 twin and 6 $\mathrm{mm}$ light cable provided satisfactory illumination for videoscopic surgery. Moreover, Magne (1999), Chamness (2002) and Boure' (2005) recommended 300-W xenon light source to perform laparoscopy.

Presurgical fasting was mandatory before any laparoscopic procedure. Seeger and Klatt (1980), Maxwell and Kraemer (1980) and Steiner and Zulauf (1999) advised fasting to decrease the content of rumen and large intestine and reduce intestinal peristalsis. It reduces risk of organ penetration during trocar introduction and improves observation of abdominal structures. This result coincided with Kolata and Freeman (1999) who added that the same is true in most animals when a ventral approach is used. Kenawy (1998), Atiba (2003) and El-Sayad et al. (2003) inserted the Veress needle in the dogs and cats caudolateral to the umbilicus and directed toward the pelvis to avoid flaciform ligament and avoid spleen injury.

Tilting and rotating the animal during laparoscopic procedures provided better exposure of area of interest. Trendelenburg position (head up) encouraged abdominal organs to slide caudally exposing $\overline{\text { Kafrelsheikh Vet. Med. J. Vol. } 6 \text { No. } 1 \text { (2008) }}$ 
cranial field. Reverse Trendelenburg position (head down) encouraged abdominal organs to slide cranially, exposing caudal field. Similar findings were described by Kolata and Freeman (1999), Bouré (2005) and Vilos et al. (2007).

Laparoscopy provided a comprehensive description of the normal laparoscopic anatomy of the abdomen (cranial and caudal regions) of goats in dorsal recumbent position. Anderson et al. (1993) described normal laparoscopic anatomy of bovine abdomen from right and left paralumber fossa in standing cows and from cranioventral midline in recumbent cows. Reticulum is recognizable by its regular contractions, while abomasum is recognized by its serosa and attachment to the greater omentum. Babkine and Desrochers (2005) observed similar findings in cattle. Some structures consistently not seen during ventral laparoscopy as lumber portion of diaphragm, dorsal part of the spleen, left kidney, dorsal ruminal sac, root of mesentery and base of the cecum. Galuppo (2002) and Babkine and Desrochers (2005) found that the dorsal and ventral content of the abdomen must be evaluated independently because it is impossible to visualize the entire abdomen from one laparoscopic position. Laparoscopic liver biopsy in goats was safe, practical and easily performed. It offered the advantage of direct visualization of liver. Monnet and Twedt (2003) added that it allowed selection of the exact site and that other diagnostic modalities often do not provide sufficient information about the liver. Warshaw et al. (1990) pointed out that US, CT and MRI techniques may miss small liver and peritoneal metastases which are ideally detected with laparoscopy. Laparoscopic liver biopsy Kafrelsheikh Vet. Med. J. Vol. 6 No. 1 (2008) 
provided a safe reliable technique to evaluate ascitis (Inabnet and Deziel, 1995). Laparoscopic biopsy allows surgeon to biopsy specific areas of liver under direct visualization. An angulated rather than perpendicular biopsy approach to the liver may result in less bleeding. Nord (1992) explained that surgeon should be careful to avoid needle biopsy directly over the gallbladder as bleeding or perforation into the gallbladder may occur necessitating cholecystectomy. Wedge biopsy of the liver is more invasive than needle biopsy, but needle biopsy yields smaller amounts of liver tissues than wedge biopsy. This result are matched with that of Pittman et al. (1988) who reported that wedge biopsy was more accurate for detecting liver diseases than needle biopsy. Seki et al. (2001) believed that wedge biopsy is suitable for diagnosis of comparatively rare diseases of liver. Post-biopsy bleeding was controlled by direct compression or electrocautery of biopsy site. Inabnet and Deziel (1995) applied Gelfoam ${ }^{\mathrm{TM}}$ soaked with topical thrombin for persistent bleeding. Bile leak is very infrequent after laparoscopic liver biopsy. Boinstein et al. (1991) managed this complication non-surgically by exploration using of drainage. It is therefore clear that laparoscopy as a minimally invasive technique considered an alternative procedure to laparotomy for diagnostic purposes, liver biopsy and providing additional information concerning the condition prognosis. Ventral abdominal approach proved useful for liver biopsies and offered good visualization of liver, gallbladder, reticulum, abomasum, intestine, spleen, reproductive system and urinary bladder in goats. 


\section{REFERENCES}

- Anderson, D.E.; Gaughan, E.M. and St-Jean, G. (1993): Normal laparoscopic anatomy of the bovine abdomen. Am. J. Vet. Res. 54(7): 1170-1176.

- Atiba, A. S. (2003): Experimental diagnostic uses of laparoscope in dogs. M. V. Sc. Thesis, Fac. Vet. Med., Tanta Univ. (Kafr El-Sheikh).

- Babkine, M. and Desrochers, A. (2005): Laparoscopic surgery in adult cattle. Vet. Clin. Food Anim., 21: 251-279.

- Bleyaert, H.F.; Brown, M. P.; Bonenclark, G. and Bailey, J.E. (1997): Laparoscopic adhesiolysis in a horse. Veterinary surgery 26:492-496.

- Bouré, L. (2005): General principles of laparoscopy. Vet. Clin. Food. Anim., 21: 227-249.

- Bouré, L. P.; Pearce, S. G.; Kerr, C. L.; Lansdowne, J. L.; Martin, C. A.; Hathaway,A. L. and Caswell, J. L. (2002): Evaluation of laparoscopic adhesiolysis for the treatment of experimentally induced adhesions in pony foals. American Journal of veterinary research 63:289-294.

- Chamness, C. J. (2002): Non disposable instrumentation for equine laparoscopy. In: Fisher, A. T. editor. Equine diagnostic \& surgical laparoscopy. Philadelphia: W. B. Saunders Company; p. 37-49.

- Dukelow, W. R.; Jarosz, S. J.; Jewett, D. A. and Harrison, R. M. (1971): Laparoscopic examination of the ovaries in goats and primates. Lab. Anim. Sci., 21: 594-597. 
- El-Sayad, G.A., Seleim, M.A. and Atiba, A.S. (2003): Experimental diagnostic uses of laparoscope in dogs. Mansoura Vet. Med. J., 6 (2): 319-331.

- Falcone, R.E.; Wanamaker S.R. and Barnes, F (1993): Laparoscopic vs open wedge biopsy of the liver. J. Lap. Surg., 3: 325329.

- Freeman, L.G. (1999): Operating room set up, equipment, and instrumentation. In: Freeman, L. G., editor. Veterinary endosurgery. St. Louis: Mosby; p.3-23.

- Galuppo, L. D. (2002): Laparoscopic anatomy. In: Fisher, A. T. editor. Equine diagnostic \& surgical laparoscopy. Philadelphia: W. B. Saunders Company; p. 7-27.

- Galuppo, L. D.; Snyder, J.R. and Pascoe, J. R. (1995): Laparoscopic anatomy of the equine abdomen. Am. J. Vet. Res. 56(4):518-531.

- Inabnet, W.B. and Deziel, D. J. (1995): Laparoscopic liver biopsy in patients with coagulopathy, portal hypertension, and ascites. Am. Surg., 61:603-606.

- Ivankovich,A.D.(1975): Cardiovascular effects of intraperitoneal insufflation with carbon dioxide and nitrous oxide in the dog. Anesthesiology 42:281-287.

- Jarosez, S. J.; Deans, R. J. and Dukelow, W. R. (1971): The reproductive cycle of the African Pygmy and Toggenburg goot. J. Reprod. Fertil., 24:119-123.

- Kenawy, A. A. (1998): Experimental laparoscopy and instrumentation in dogs. Assiut Vet. Med. J. 39(78): 51-62. 
- Kolata, R. J. and Freeman, L. J. (1999): Access, port placement and basic endosurgical skills. In: Freeman, L. G., editor. Veterinary endosurgery. St. Louis: Mosby; p.44-60.

- Liem, T.; Applebaum, H. and Herzberger, B. (1994): Hemodynamic and ventilatory effects of abdominal $\mathrm{Co} 2$ insufflation at various pressures in young swine. J. Pediatr. Surg. 29:966-969.

- Magne, M. L. (1999): Laparoscopy: Instrumentation and technique. In: small animal endoscopy 2nd ed. by Tams, T. R. (1999) Mosby, Inc; p. 367-375.

- Maxwell, D. and Kraemer, D. (1980): Laparoscopy in cattle. In: Harrison, R. M. and Wildt, D. E., editors. Animal laparoscopy. Baltimore: Williams \&Wilkins; p. 133-57.

- Monnet, E. and Twedt, D. C. (2003): Laparoscopy. Vet. Clin. Small Anim., 33: 1147-1163.

- Muir, W. W. and Hubbell, J. A. E. (1989): Anesthetic procedures and techniques in ruminants. In: hand book of veterinary anesthesia by Muir, W.W. and Hubbell, J. A. E. eds. Chapter 21 The C. V. Mosby Company.

- Nord, H. (1987): Technique of laparoscopy. In: Sivak, M., editor. Gastroenterologic endoscopy. Philadelphia: WB Saunders; p. 9941029.

- Nord, H. J. (1992): Complications of laparoscopy. Endoscopy 24:693-700. 
- Pittman,C. E.; Buss, D. A. and Sterchi, J. M. (1988): Detection of liver involvement in Hodgkin's disease. J. Surg. Oncol., 38:265-266.

- Prescott, R. (1980): Optical principles of laparoscopy. In: Harrison, R. and Wildt, D. editors. Animal laparoscopy. Baltimore: Williams \&Wilkins; p. 15-29.

- Seeger, K. H. and Klatt, P. R. (1980): Laparoscopy in the sheep and goat. In: animal laparoscopy by Harrison, R. M. and Wildt, D. E. eds. Chapter 6 Willimas \& Wilkins Baltimore, London.

- Seki,S.; Sakaguchi,H.; Kadoya,H.; Morikawa,H.; Kitada,T.; Habu,D.; Tamori,A.; Nishiguchi, S. and Shiomi, S. (2001): Laparoscopic wedge biopsy of the liver with use of an ultrasonically activated scalpel. Digestive Endoscopy, 13: 17-20.

- Smith,C. L. Dowling, B. A. and Dart, A. J.( 2005): Recent advances in equine abdominal surgery. The Veterinary Journal 170(1): 41-51.

- Steiner, A. and Zulauf, M. (1999): Diagnostic laparoscopy in the cow. Schweiz. Arch. Tierheilkd., 141: 397-406.

- Vilos, G. A.; Ternamian, A.; Dempster, J. and Laberge, P. Y. (2007): Laparoscopic entry: a review of techniques, technologies, and complications. J. Obstet. Gynaecol. Can., 29(5): 433-465.

- Warshaw, A. L.; Gu, Z. and Willenberg, J. (1990): Preoperative staging and assessment of resectability of pancreatic cancer. Arch. Surg., 125:230-233. 
التوصيف التشريحى للبطن فى الماعز بالمنظار الجراحى وأخذ عينه تشخيصيه من الكبد د./ مصطفى قاسم - د.//رضان عبد/لواحد - د.//سعير الجندى" - د.// محصود الكمار (قسم الجراحة و قسم التشريح* - كلية الطب البيطرى - خامعة الاسكندريه)

استهفت الدراسة توضيح الأهمية العملية لاستخدام المنظار الجراحى فى الوصف النتريحى لمنطقة البطن وإمكانية اخذ عينات من الكبد فى إناث الماعز • تم إجراء هذه الرسالة على عدد 10 إناث من الماعز البلاى يتراوح وزنها ما بين 25-30 كج وعمرها ما بين 1.5- 3 عام حيث استخدم الحيوانات فى دراسة الوصف التشريحى ثم استخدم نفسها لأخذ عينات من الكبد. بعد الفحص مل الإكلينيكي للحيوان وتخديره وتحضيره لإجراء المنظار البطنى نم وضع الحيوان مستلقيا على الظهر وإدخال إبرة فيرس من خلال منطقة السرة لضخ ثانى أكسيد الكربون داخل الفراغ البريتونى. بعد ذلك تم إدخال المنظار مكان الإبرة من خلال كانيولا أساسيه. كما تم ايلاج ثلاثة كانيولات ثانوية لإدخال المعدات اللازمة للتعامل مع أنسجة الجسم المختلفة كالجفت الماسك وجفت الكى والمقص الجراحى وإبرة العينات القاطعة. وقد أوضحت الدراسة أن استخدام الوضع السفلى فى الماعز مع إمالة ولف الحيوان من جانب لآخر أثناء إجراء المنظار يتيح رؤية أفضل للاماكن المراد فحصها. كما تجلت فائدة المنظار للروئية العينية الدقيقة للأعضاء الداخلية لمنطقة البطن فى اناث الماعز المستلقية على الظهر. ففى حالة رفع الجزء الأمامي للجسم ظهر الحجاب الحاجز والكبد والثبكة الوراقية والمنفحة والمراراة والطحال أما فى حالة رفع الجزء الخلفى نم رؤية المثانة البولية والرحم بقرنيه الأيمن والايسر والمبياض وقناتى فالوب. كما بدا أيضا سهولة وامان المنظار فى اخذ العينات من الكبد من حيث الروئة المباشرة لمكان العينة. ومما نقدم يتبين ان المنظار الجراحى للبطن يساعد على الرؤية المباشرة للأعضاء الداخلية ورسم خريطة تشريحية وتوصيفية واضحة وكاملة لمنطقة البطن وإجراء بعض العطليات كأخذ عينات من الكبد بغرض التشخيص الباثولوجى وغيره. 